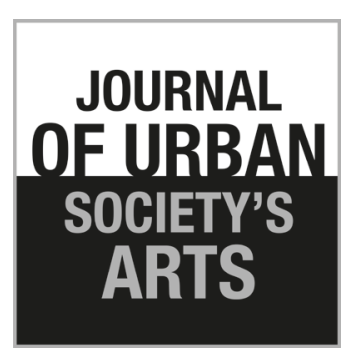

Volume 5 Nomor 2,

Oktober 2018: 87-93

\section{“Ora Minggir Tabrak": Electronic Dance Music (EDM), a Montage of The Time-Image}

\section{Citra Aryandari}

Program Studi Etnomusikologi, Fakultas Seni Pertunjukan

Institut Seni Indonesia Yogyakarta

Telp.081804141719,E-mail: citrasudarmanto@yahoo.com

\begin{abstract}
Electronic Dance Music (EDM) is a music genre which has been perceived in negative way because closely related to night life in which alcoholic drinks and illegal drugs. The beatings of the rhythm presented can arouse a desire to shake the body, giving instant pleasure to escape from the weariness of life. Although it could be said that this music genre is able to help the listeners to forget "the problems" of life, however, it is very rarely that the academic circle looked into this music genre and make it as a subject of interesting studies. This article is written out of subjective observations in social sphere on subjects containing a lot of secrecies and initially considered as a taboo to be discussed. The existence of EDM in line with the technological developments as montage of the time-image related with complexity of social relations, attempting to embark on a new identity in power, politics, and ideological trappings. The phenomenon comes into sight specifically in the song of "Ora Minggir Tabrak", literally means if you get on my way I will hit you, a soundtrack of Ada Apa Dengan Cinta 2 feature film. And it obviously could be seen in talent hunting for EDM musicians program broadcast by Net TV (the ReMix), and several other big events with internationally standard organized annually, such as DWP (Djakarta Warehouse Project); and Dreamfield at GWK Bali, which are worth-discussing amidst the hustle and bustle of music market in Indonesia.
\end{abstract}

Keywords: Electronic Dance Music; “Ora Minggir Tabrak”; montage; time-image

\begin{abstract}
ABSTRAK
Electronic Dance Music (EDM) sebuah genre musik yang lekat akan persepsi negative karena lekat dengan dunia malam yang sarat obat-obatan terlarang dan minuman alcohol. Hentakan irama yang dihadirkan mampu menggugah hasrat untuk bergoyang memberikan kenikmatan sesaat untuk sekedar melupakan penatnya kehidupan. Meski dapat dikatakan musik genre ini mampu membantu pendengar melupakan problema hidup, tetapi sangat jarang kaum akademisi melirik genre musik ini menjadi sebuah kajian yang menarik. Tulisan ini merupakan hasil dari sebuah pengamatan subjektif di ruang social yang awal mulanya sarat akan ketertutupan sehingga tampak tabu untuk didiskusikan. Kehadiran EDM seiring dengan kemajuan teknologi merupakan montase imaji waktu yang berkait dengan kompleksitas relasi social masyarakat yang mulai mencari identitas baru ditengah permainan kekuasaan, politik dan ideology. Fenomena ini secara spesifik tampak dalam lagu "Ora Minggir Tabrak" soundtrack film Ada Apa Dengan Cinta 2 dan lebih luas dapat dilihat dalam ajang pencarian bakat musisi EDM yang ditayangkan Net TV (the ReMix) serta beberapa event besar bertaraf internasional yang dilakukan secara annual, seperti DWP (Djakarta Warehouse Project); dan Dreamfield di GWK Bali, menjadi layak didiskusikan ditengah hiruk pikuk pasar musik di Indonesia.
\end{abstract}

Kata kunci: Electronic Dance Music; "Ora Minggir Tabrak”; montase; imaji waktu 
Intro

At the end of 2015, my colleagues from abroad visited Bali for the first time and asked me to accompany them on their journey, considering that Bali was a very intense research subject I was working on. In welcoming the arrival of colleagues, I prepared a list of some popular places that are used to be tourism destinations in Bali, and how shocked I was, my colleagues turned down the list and gave the list they wanted to visit. One list of places they want to visit is Potato Head Beach Club, Seminyak. This place offers a beautiful view of the blue ocean ready to pamper anyone's eyes. Besides being famous for its sea views and private beach, Potato Head Beach Club is also famous for its unique architecture. Hundreds or thousands of recycle windows adorn the outer walls. This beach club presents live performances of performing music every day from local to international DJs. A very non-Balinese space, but in Bali.

Entering Potato Head Beach Club there is some money to pay and it can be said to be quite expensive, but that night there was a show from Marsmello an international DJ who was famous in the EDM industry. Rave party is held from 11:00 a.m. to 2:00 a.m. A number of local and international visitors seemed to fill the space. This is quite astonishing because of the enthusiasm of the masses who packed the room.

In addition to this experience, in the same year a friend posted his anxiety on social media Path. He shared his sadness at not being able to buy a DWP ticket for his 13-year-old daughter. DWP is a music event that is visited by around 90 thousand people per year with ticket prices between 1-2 million rupiahs. Fantastic enough isn't it?

The movie of Ada Apa Dengan Cinta 2 (shortened AADC 2), released 2016 presents Yogyakarta as one of its settings. As a locus enriched by plenty cultural texts, some local texts are chosen to strengthen the nuances of the city. Ora Minggir Tabrak song is one of them. Playful children song is represented as hip-hop song of EDM (Electronic Dance Music) mode by Kill the DJ and Libertaria as a soundtrack of AADC 2 movie.
Kill the DJ and Libertaria appear in a scene portraying a glamorous atmosphere cannot be separated from the action of the DJ (Disk Jockey), a title given to a skillful person in choosing and playing musical records to create a sort of musical journey for the audience. A DJ acts as a controller and selector of music to be played in accordance with the atmosphere as well as the type of music to be played. In the process of selecting the songs, the DJ will combine particular technical skills with knowledge in the field of music in order to create a spectacular live show loved by the audience. The glamorous night life is certainly a "reality" sign of an image of a modern city.

Boshe (a club in Yogyakarta) on 3 May 2016 presented a program entitled "Locally Session" displaying "Ora Minggir Tabrak" sung by DJ Tehara as one of the leading songs to send a signal that the entertaining evening would soon come to an end marked by increasingly louder beats. A simple tone of the song got a spectacular response from the audience. The "Ora Minggir Tabrak" song is a Javanese song sung by children while they are playing and now get a particular place and sung for a different need. Through $A A D C 2$ the movie, the slowly disappearing children song, is now back popular and become the hit that needed to be responded quickly by businessmen running entertainment places to meet the market demand. "Ora Minggir Tabrak" has regained popularity in such a short time. Now, the art has become more integrated in the economy and used to encourage people to consume through a big role played by commercials, in addition to the fact that art has become a separate commercial goods (Strinati, 2005).

From the subjective experiences that I told above, it became my strong reason to get to know the EDM genre. How is EDM able to break down the cultural barriers and interest the public as a montage of the time-image?

The morality panic remains lingering around whenever the glamorous night life being discussed. The morality panic is understood as a media movement resulted from the perception that an individual, a group, or a culture with divert outlook could create a threat to the public (Cohen, 
2011). However, postmodernism has broken some partitions to enable people looking deeper into the glamorous night life.

This work aims to find out a deep image of EDM scene in Indonesia, starting from its history, development to the resonance of culture made in the middle of identity crisis problem that is still debatable as hot issues existing around post-colonial countries. The EDM's existence in Indonesia along with the advancement of technology can be seen as a complexity of social relation that starts questioning its new identity in the middle of power, politic, and ideology constellation becomes an interesting research area.

The EDM's presence in the world popular performing art industry - seen from the viewpoint of postmodernism - is a trend leading to explicit and blunt combination of various kinds of musical trends and genre in direct and conscious way (Hebdige, 1986). This combination includes the repetition of combining songs recorded from the same era or otherwise on the same recording, until it 'arrives' to be music, e.g. sound and different instruments targeting to create a new subcultural identity. Sub culture identity is symbolically expressed on the style creation which is not only exists as a counter of hegemony or even a way out from the social tension (Hebdige, 1995).

EDM offered by DJ with its popular stars become new reference for local DJ's body in Indonesia. Un-avoided cultural meet makes this music genre to be new reference for local bodies that are so familiar with embodied culture. Marzuki Mohammad (Kill The DJ) is one of them, a musician from Yogyakarta enlivening Indonesia EDM scene by performing children song sung by rap within EDM's beat. DJ' scene offering locality makes EDM to be more acceptable trough every cultural border.

\section{Verse 1}

The children song "Ora Minggir Tabrak" packaged interestingly into the format of EDM (Electronic Dance Music) music genre is an interesting innovation in the hustle bustle of the Indonesian music market. The innovation is related with collage, pastiche (art work), and quotations, a combination of different genres-musically and historically-coupled with random and selective combining.

EDM as a music genre which has undergone a decreasing moment until it regained its popularity later. The history recorded that the EDM started in 1970, and according to Rawley Bornstein, an MTV programmer, "EDM is the new rock and roll". This idea has become a reality since the EDM is not segmented any more, and almost every minute the radio plays the EDM songs, even also a national TV station (Net TV) once ran a program to search new DJ talents program called The Re-Mix, and a good number of festivals organized for this music genre. Nowadays, the DJs perform as if they were rock-star.

In the beginning, the EDM is an electronic music produced to be played at night clubs, or places used for people to dance. The Electronic Dance Music is usually categorized on beat per minute (bpm). The slowest EDM tempo is between 60 and $90 \mathrm{bpm}$, while the genre such as speed core may surpass the level of $240 \mathrm{bpm}$. The EDM movement appeared when the disco music started to leave the process of composing by way of traditional orchestration, and began using electronic musical instruments, such as synthesizer and drum machine in the 1970s. In those eras, many producers and DJs conducted experimentations using blend mixing technique (Bennett, 2000), by combining several discs so as to produce new sounds with different tonal texture. Later on, this technique further developed following technological development.

The EDM developed in line with the development of space and time. Ibiza, a town in Balearic island of Spain, had explored local texts and developed them into Balearic beat, now a very popular beat in EDM genre. Balearic is a place surrounded by beautiful beaches and has become a very popular tourist destination in Europe, making Ibiza crowded by tourists, a town now dotted by a lot of resorts and beach clubs. A beach club in Ibiza, to quote a brochure, offers a 'rave party' clubbing, starting from dusk until dawn, giving birth to the local-styled EDM following the demand of the market. And the Balearic beat became a subgenre 
known widely and attracted the attention of beach clubs in other areas. In addition to that, the Balearic beat recording industry got a tremendous response from the market. Almost all beach clubs all over the world now make Balearic beat as soundtrack at times when the club doesn't organize a musical event. Even a popular beach club in Bali also uses Balearic beat as a room sound-space when there is no DJ presented.

By the end of the 1980s and the beginning of 1990s, in Detroit, emerged another subgenre of EDM. The noise of the city became a reference in the innovation process. The 'Industrial Noise' is a sign of urban life similar to street sound-space, factory machine, shopping mall, and the noise of the city became the basic idea for the development of EDM music, and this subgenre later known as techno music. It developed rapidly in the crowded cities dense with noises. It is assumed that Duesseldorf, an industrial city in Germany, is the home for the development of techno music. Ralf Hutter and Florian Schneider, the students of classical music, who were frustrated by the classical music training in the conservatory, started to conduct experiments by playing music using computers which enabled them to compose music with high level of complexity combined with sound-space available in Duesseldorf, Germany. Hutter and Schneider then established a techno music group called Kraftwerk known until nowadays and recorded in the EDM history(St John, 2006).

In Indonesia, the EDM enjoyed reasonable development. It could be seen through the spreading of EDM festivals all over the country. In 2008, Blowfish Warehouse Project tried to attract Indonesian's market, and it changed its name to Djakarta Warehouse Project (DWP). Organized by Ismaya Live, the DWP seemed to become a "big holiday" for music lovers. Since 2008 until recently, the DWP programs continue to attract the audience; it even has become the biggest EDM festival in the world starred by world known DJs and EDM musicians and attended by thousands of spectators.

In addition to the DWP, the EDM festival which attracted the local as well as foreign audience was Dreamfield taking place at Garuda Wisnu Kencana (GWK) Bali. Since first organized in
2014, it was attended-according to a recordby more than ten thousand spectators. Besides the Dreamfield, another EDM festival organized in Bali since early 1999 was Ultra Music Festival.

The EDM development in Indonesia is marked by the organization of international festivals attended by thousands of spectators and also the broadcasting of DJ talents hunter by TV stations. The Re-Mix, a competition format program broadcast by Net TV, was also an obvious presence of the EDM in Indonesia. This program is an adaptation of a similar show which has gained a big success in television programs in Vietnam in early 2015. With the capital as a background, the television program seemed to be interested more in taking and recycling the trend rather than spreading the innovations deemed financially risky. The success of the EDM competition in Vietnam led Tripar Multivision as the producer of The ReMix being confident to organize it in Indonesia. Of course, the confidence was also based on the "reality" of the lifestyle trend in the society. Television programs are signs that could be called the social texts (Fiske, 2010). Texts that represent various values in the society.

\section{Chorus}

The digital technology has opened the way for the emergence of a new era in sound recording. The analogue tape machine has been replaced by computer. The computer has the ability to store and produce sound recording far more accurate that the old analogue recording machine and can produce elements different from 'white noise', even though frequently considered as imperfection, but nonetheless it gives a nuance of color to the recording itself. The digital technology has also facilitated a number of other things during the recording process, including making samples of various kinds of short music utilizing keyboard or synthesizer, drum pad, and also including the voice using microphone which later kept in the MIDI form. Various instruments were combined altogether so as to prepare a composition and kept in the computer memory. The samples might be manipulated as a source of sound at 
an unimaginable scale. The sampling technique provided an effective way in taking sound from the origin and repeat them into pieces in order to produce a new music.

The EDM's presence in the world popular music industry-seen from the viewpoint of postmodernism - is a trend leading to explicit and blunt combination of various kinds of musical trends and genre in direct and conscious way (Hebdige, 1986). This combination included the repetition of combining songs recorded from the same era or otherwise on the same recording, until it 'arrived' to be a music, sound and different instruments targeting to create a new subcultural identity (Hebdige, 1995).

Creativity in EDM has resulted in a changing role of musician, particularly the DJs. A DJ can do re-mixing of the available voices of artists and make new interpretation by processing and rearranging them to become a new trend. This situation shows the blurring role of musician in the production process of EDM. A DJ right now can claim her/ himself as composer, arranger, producer and artist altogether.

This is an interesting subject to discuss, especially viewed from postmodernism approachthat it is not only music which has been so mixed beyond limit, but also the role of the musicians, in this case also the blurring role of DJ. It is definitely different from rock band or conventional music group. The shifting role brings consequence to a DJ. DJ Melechi (1993) states that the young generation is fed up with the convention of rock performance, leading to the emergence of scene without a star, a performance, and an identification (Bennett, 2000). As a status, a DJ has the possibility to throw away the convention on prestige and the praise frequently received by a rock star.

Thus, the subculture identity is formed in line with the postmodernism surround it. Subculture is understood as a cultural symptom generally formed based on age and class. Symbolically, it is expressed in the form of the creation of style and not only a resistance against the hegemony or a way out of social strains (Hebdige, 1993).

The DWP and the Dreamfield—which play their role in the music market in Indonesia_ provide a legitimate EDM festivity. DWP, Dreamfield, Ultra and a lot more EDM events resemble a carnival in which all voices are in one rhythm. There is no race higher that the other, no men and women, all persons united in togetherness. Laughter and social hierarchy merge and mix without limits in the rhythmal beat.

\section{Verse 2}

Back to the "Ora Minggir Tabrak" in EDM genre, presented by Kill the DJ initiated by Marzuki Mohammad (the founder of Jogja Hip-Hop Foundation) who admitted that he was inspired by his experiences in his childhood. The song, according to Marzuki Mohammad in an interview, "It fits for $A A D C 2$ because life is just like that. If you don't give way you will be hit." The same also today, we cannot remain being ignorant while time and life are moving on (Marzuki, 30 April 2016).

For Marzuki, "Ora Minggir Tabrak" song carries a very meaningful message in the story of Rangga and Cinta (the leading characters in AADC 2). When they were separated they had to go through their respective life until they met again, and that was the philosophy of life reflected by Kill the DJ in that song, meaning that if you didn't continue to go on with your life, you would be hit.

Kill the DJ started his career in music in 2001, and established Jogja Hip-Hop Foundation (JHF) in 2003. Marzuki admitted that the development of rave party in Yogyakarta had been the main reason why he chose the EDM way. The name Kill the DJ has been selected because of his refusal against an idol (DJ) and that it was about time to inspire his own life with what he has gone through, so that JHF is there to provide a space without a wall providing shelter for the hip hop lovers in Yogyakarta (Marzuki, 23 July 2014). Yogyakarta with the Javanese culture knows pantun (traditional poetry) called parikan, and later it has been developed by JHF and used as song lyrics.

The $A A D C$ 2, a movie catering the young generation, directed by Riri Riza, related on the friendship of four girls with their respective love stories. One of them was Cinta. The story began when the four girls went on vacation to Yogyakarta. 
The city has quite a number of attractive tourist destinations to visit. Unluckily, the first place they visited was a night club, not the keraton (palace) and other historic places. Rave party was the first scene of tourist destination visited by the four girls.

As an attractive entertainment, rave party is rarely discussed, even though in reality, street banners offer entertainment and drinks appeared on the corners across the city. There is one thing that makes it easier to differentiate between Yogyakarta and Jakarta. In Jakarta, the metropolitan city, particularly along the main streets from the airport to the city center of Sudirman-Thamrin area, in several places one likely spot ballyhoos or street banners announcing religious gathering, such as religious classes delivered by certain Habibs (Muslim clerics) and other religious events. On the contrary, in Yogyakarta, a city considered of culture and education, it is difficult to find similar street banners. There are a lot of banners and ballyhoos on night entertainment offering music, (sexy) dance and alcoholic drinks which — in many casesthe prices are even mentioned straight away. In fact, this is not a phenomenon, because since the beginning of the new millennia, similar banners have appeared in many entertainment places in Yogyakarta.

Rave culture were grass-roots organized, antiestablishment, unlicensed all-night drug-fueled dance parties held in abandoned warehouses or an open field (Siokou, 2002). These days, we need paying for a branded party at popular riverfront nightclubs where age and status, rather than DJ expertise and dancing, shape your experience. Electronic Dance Music (EDM) is a music genre which has been perceived in negative way because closely related to night life in which alcoholic drinks and illegal drugs. It looks at whether certain factors influence the frequency of illegal drug and alcohol use: the frequency of going to certain nightlife venues in the previous month (such as, pubs, clubs or goa parties); listening to rock music, dance music or southern and funky music; or sampling venues (such as, clubs, dance events or rock festivals). The question of how these nightlife variables influence the use of popular drugs like alcohol, MDMA, cannabis, cocaine and amphetamines is addressed
(Van Havere, Vanderplasschen, Lammertyn, Broekaert, \& Bellis, 2011).

"Ora Minggir Tabrak" sung by Kill the DJ in a rave party scene, has a lot of meanings if it is analyzed as a text. The parikan usually used in the children songs has changed its meanings and functions when applied in different spaces. If we look deeper into the "Ora Minggir Tabrak", the lyric has a philosophically penetrating meaning in the context of the recent social condition.

Following is the lyric of "Ora Minggir Tabrak":

Minggir Ra Minggir Tabrak

Mijil-tuwuh, urip-urip, muksa-pati

Esuk-awan, surup-sirep, rina-wengi

Saiki, neng kene, ngene, dilakoni

Semeleh, kudu gelem, lan nggelemi

Wiji wutuh, wutah pecah, pecah tuwuh, wiji maneh

Laku, lakon, dilakoni kanthi semeleh

Obah mamah, mingset nggeget, nyikut

nggrawut, ngglethak penak

Nggir ra minggir tabrak wong urip kudhu

tumindak

[give way otherwise will be hit

born-develop, live and to live, disappear-die

morning-noon, twilight-disappearing, noon-

evening

now, here, like this, undergo

sincere, should be willing, and willing

seeds are intact, fell and broken, broken and

grow, again become seed

behave, behavior, play, do it sincerely

move and eat, disparaging and biting, elbowing scratching, lie down comfortably

give way otherwise will be hit, life should be gone through]

That lyrics sounds fitting if seen from the love story of Rangga and Cinta characters, where they are initially separated in distance and space, and have lot more unsettled problems, however, life goes on. At the end, they meet again and all problems are settled and life moves on. If it is connected to a larger social condition in Yogyakarta, the presence of rave party in a city with cultural identity still considered honorable, clearly it provides two things which are contradictory, but life is still going on, and the economic struggle ought to be taken into. 
The market demands the presence of a new room that offers freedom.

\section{Chorus}

"Ora Minggir Tabrak" as a text analyzed with a critical approach. The EDM genre song in a move soundtrack narrating on a touristic trip in Yogyakarta in rave party scene indicates a "reality" on the presence of night entertainment place as a tourist destination in Yogyakarta that should be thoroughly considered.

The circulated moral panic has been attacked by the market demand. In his article, "Dunia Lain di Yogyakarta: Dari Jatilan hingga Musik Elektronik" (Another World in Yogyakarta: From Jatilan to Electronic Music), Max Ritcher said that electronic music has created a temporary autonomous zone, which has liberated the participants from the shackles of the state and the commercial power. Performances in commercial zones in Yogyakarta, to a certain level, allow participants to challenge and go beyond the role of gender limited by the state conservatism and the global commercialization of commodity (Heryanto, 2008). Right now, the image of women has been liberated from the shackles of moral set-up. The four girls in $A A D C$ 2 have stressed that the dance floors belong to whoever wants to dance. The shackles of moral setup seem to have been broken by space-time. "Ora Minggir Tabrak" textually referred to that matter.

\section{Ending}

The EDM has explored the world of the young generation in various forms in line with space and time. The phenomenon of the rise of EDM likened a montage in a film. Starting from a disco club and then spread like epidemic without borders throughout the world. As a montage of the time-image, EDM is very fluid, many formations are entwined which is beyond any efforts to map out its presence.

EDM as a culture of the young generation has broken the tone in the legitimate festivity of a carnival in which all sounds are represented in one and only rhythm. There is no race higher than another, there is no men and women, all persons are united in togetherness. Laughter and social hierarchy are melting in the beating of the rhythm. The Electronic Dance Music offers resistance and freedom.

\section{References}

Bennett, A. (2000). Popular Music and Youth Culture: Music, Identity and Place. Mobile Media \& Communication. https://doi.org/10. 1177/2050157912460033

Cohen, S. (2011). Folk devils and moral panics: The creation of the Mods and Rockers. Folk Devils and Moral Panics: The Creation of the Mods and Rockers. https://doi.org/10.4324/ 9780203828250

Fiske, J. (2010). Television culture: Second edition. Television Culture: Second Edition. https://doi. org/10.4324/9780203837153

Hebdige, D. (1986). Postmodernism and 'The Other Side.'JournalofCommunicationInquiry.https:// doi.org/10.1177/019685998601000206

Hebdige, D. (1993). From culture to hegemony. The Cultural Studies Reader.

Hebdige, D. (1995). Subculture: The Meaning of Style. Critical Quarterly. https://doi.org/ 10.1111/j.1467-8705.1995.tb01063.x

Heryanto, A. (2008). Popular culture in Indonesia: Fluid identities in post-authoritarian politics. Popular Culture in Indonesia: Fluid Identities in Post-Authoritarian Politics. https://doi. org/10.4324/9780203895627

Siokou, C. (2002). Rave culture. Youth Studies Australia.

St John, G. (2006). Electronic Dance Music Culture and Religion: An Overview. Culture and Religion. https://doi.org/10.1080/014383006 00625259

Strinati, D. (2005). An Introduction to Theories of Popular Culture. PsycCRITIQUES. https://doi. org/10.1037/021123

Van Havere, T., Vanderplasschen, W., Lammertyn, J., Broekaert, E., \& Bellis, M. (2011). Drug use and nightlife: More than just dance music. Substance Abuse: Treatment, Prevention, and Policy. https://doi.org/10.1186/1747597X-6-18 